\title{
APPLICATION OF VALUE ENGINEERING IN PROJECT ROAD MAINTENANCE ACTIVITY AT THE PUBLIC WORKS DEPARTMENT OF SPATIAL PLANNING IN GROBOGAN
}

\author{
Hari Budi Prasetyo ${ }^{1}$, Rachmat Mudiyono² \\ Master of Civil Engineering, Sultan Agung Islamic University ${ }^{1,2}$ \\ Corresponding Author Email: rachmat@unissula.ac.id
}

\begin{abstract}
One of the most frequent tasks of Public Works and Spatial Planning (PUPR) of Grobogan Regency is the handling of road damage with routine road maintenance. Implementation of material procurement is done contractually with provider of goods / services while for the implementation of activities in the field implemented by UPTD area according to location of activity. So in the implementation of road maintenance activities PUPR Service Grobogan District requires a method of engineering value or commonly called Value Engineering in order to be implemented efficiently and optimally. The purpose of this study is to determine the cost efficiency in the implementation of road maintenance; know the cost components that have the potential to be saved / streamlined in the implementation of road maintenance and also to know the extent to which this value engineering can be applied to the implementation of road maintenance on a self-managed basis. The method used is descriptive qualitative with analytical technique using value engineering to answer the background of problem and purpose. The results of this study indicate that contractual road maintenance is cheaper because it does not rent equipment but has a short plan life of maximum 3 years. While road maintenance is done by self-managed has a plan life of up to 5 years. The cost of renting equipment is a very possible component to save. Value engineering also yields a final conclusion that road maintenance work carried out with self-managed systems has a short and efficient procedure; better road quality and faster processing times compared to conventional systems.
\end{abstract}

Keywords: Grobogan District; Road Maintenance; Value Engineering.

\section{INTRODUCTION}

Natural and environmental factors such as changes in time, temperature, weather and so on have caused damage to unavoidable pavement surfaces. These damages affect the level of service and road performance. Periodic road repairs and maintenance are carried out to raise the level of service and road performance.

Department of Public Works and Spatial Planning Grobogan District is a technical agency in charge of roads and bridges in Grobogan District. One of the most frequent tasks is the handling of road damage with routine road maintenance carried out in self-managed manner. Implementation of self-management in outline is the planning activities and implementation activities carried out by the Department itself.

For the implementation of material procurement contracted with providers of goods / services while for the implementation of activities in the field implemented by the UPTD area 
according to the location of the activity. So in the implementation of road maintenance activities Department of Public Works and Spatial Planning Grobogan District requires a method of engineering value or commonly called Value Engineering in order to be implemented efficiently and optimally.

Implementation of Value ngineering is very important to provide cost savings in a project but at the same time be able to bring alternate items as a recommendation for the parties concerned. Value Engineering analysis in the research is done by comparing between the implementation of conventional road maintenance and by self-management.

Based on the above description, can be formulated problems in this study as follows:

1. How much cost efficiency is achieved in the implementation of road maintenance on a self-managed basis;

2. What are the cost components that have the potential to be saved or efficient by using value engineering on a self-managed road maintenance project to obtain the most efficient cost; and

3. To know the extent to which this efficiency can be applied to a road maintenance project on a self-managed basis.

\section{LITERATURE REVIEW}

According to the Society of American Value Engineers in Suharto (1995), value engineering is an organized and systematic effort to apply a technique, that is, the technique of identifying the function of a product or service aimed at fulfilling the economic function of the lowest price.

Meanwhile, according to L. D. Mile quoted from Boyd and Sudinarto (1995) defines value engineering as an organized and creative approach to identify unnecessary costs such as costs that do not provide quality, usability, good looks or desirable characteristics.

Value engineering aims to develop alternatives and leave unnecessary at the lowest cost but its performance remains the same or even better. Thus value engineering is able to distinguish and separate between necessary and unnecessary so as to save.

The implementation of value engineering according to Soeharto (2001), the process follows a systematic methodology of Value Engineering Job Plan (RK-RN). The order is to define the problem; formulate opinions; creativity; analysis; and presentation. 
In Indonesia the pattern of handling maintenance work can be done through two mechanisms that are self-managed or contracted using local contractor / area. Selection of the handling of the work should take into account local conditions and circumstances. Both self-managed and contractor use have advantages and disadvantages.

According to Presidential Regulation no. 54 Year 2010 self-managed is a procurement activity of goods / services where the work is planned, done and / or supervised by K / L / D / I as responsible for the budget, other government agencies and / or community groups. In general, this handling pattern is carried out for periodic maintenance work, but it is also possible for routine maintenance work if the technical agency concerned does not have a UPR or equipment that is inadequately owned.

\section{METHODOLOGY}

This research is a case study implementing road maintenance project at the Grobogan Regency Public Works and Spatial Planning Office through value engineering which aims to get the best value among self-management and contractual (conventional). To achieve these objectives, this study used a qualitative descriptive method, the method of research that is designed to gather information about the circumstances that are happening.Descriptive method according Sugiyono (2005: 21), is a method used to describe or analyze a result of the study but not used to make conclusions more large,

The collection of data related to the implementation of road maintenance system obtained from Grobogan Regency Public Works and Spatial Planning Office. These data are fees, materials, labor, while the data of field observations made through direct field measurements and observations.

\section{Field observations}

Road maintenance system observed are classified by two systems of self-management system and a conventional system.

The data required in each system include:
a. Path characteristic data
b. Ingredients (material), the cost and time of implementation.

\section{Interview}

This technique is done by way of question and answer with individuals concerned with research purposes. Interviews were conducted to get a goal value engineering road 
maintenance between self-management and contractual systems make use of three variables, namely the maintenance of the quality of the procedure; time and quality.

\section{Literature review}

This technique is done by collecting theories from a variety of reading materials, such as books, journals, and research reports relevant to supporting and making the argument of this research.

The analysis used to answer the problem formulation in this study is Value Engineering. Value Engineering methods used for this study are:

1. Phase information

This stage is the initial stage of VE. Activities in this phase are: understanding the initial design concepts, understand the problems that occurred, most recently confirmed the concept of the project, visited the site, looking for as much information about the project.

2. Function Analysis Phase VE

This stage is the stage which distinguishes the method Value Engineering with other cost saving methods. Activity at this stage include determining daeri function of each component of work, identify problems of self-managed, determine the components of the work item for further analysis.

\section{Creative stage}

This stage is the stage of development as much as possible alternative to the usual fulfill the functions of the primary or principal.

4. Evaluation phase

This stage of analyzing the input of ideas and alternatives. Perform analysis of the advantages and disadvantages of each alternative, if there is an idea that does not deserve to be analyzed then the idea should be eliminated.

\section{Development phase}

In the phase of development of all the ideas that are designed extended in workable solutions

\section{DISCUSSION AND ANALYSIS}

The location of the project for routine road and bridge maintenance activities in the Public Works and Grounding Service Unit of Grobogan District covers nineteen (19) sub- 
districts located in Grobogan District of Central Java. The location of the project that became the study area in this study is routine maintenance of roads in Purwodadi District.

And here are the details of the technical specifications and the Self Estimate Price for each of these specifications:

Tabel 1. Self Estimate Price

\begin{tabular}{|c|c|c|c|c|c|c|}
\hline \multirow{2}{*}{$\begin{array}{c}\text { No } \\
1\end{array}$} & \multirow{2}{*}{$\begin{array}{l}\text { Commentary } \\
\text { White Crushed Stone } \\
15 / 20\end{array}$} & \multicolumn{2}{|c|}{ Quantity } & \multirow{2}{*}{$\begin{array}{c}\begin{array}{c}\text { Unit Price } \\
\text { (Rp.) }\end{array} \\
141,000\end{array}$} & \multirow{2}{*}{$\begin{array}{r}\text { Cost (Rp.) } \\
13,536,000\end{array}$} & \multirow[t]{2}{*}{ Quantity (Rp.) } \\
\hline & & 96.00 & M3 & & & \\
\hline 2 & $\begin{array}{l}\text { White crushed stone } 5 / 7 \\
\mathrm{~cm}\end{array}$ & 38.00 & M3 & 157,500 & $5,985,000$ & \\
\hline 3 & sand & 57.00 & M3 & 167,000 & $9,519,000$ & \\
\hline 4 & sirtu & 10.93 & M3 & 157,000 & $1,716,638$ & \\
\hline 5 & AIDS & 21.00 & Set & 270,000 & $5,670,000$ & \\
\hline 6 & Crushed $3-5 \mathrm{~cm}$ & 85.00 & M3 & 329,600 & $28,016,000$ & \\
\hline 7 & Crushed $2-3 \mathrm{~cm}$ & 22.50 & M3 & 343,700 & $7,733,250$ & \\
\hline 8 & Crushed $1-2 \mathrm{~cm}$ & 19.00 & M3 & 352,700 & $6,701,300$ & \\
\hline 9 & $\begin{array}{l}\text { Crushed stone from } 0.5 \text { to } \\
1 \mathrm{~cm}\end{array}$ & 15.00 & M3 & 311,300 & $4,669,500$ & \\
\hline \multirow[t]{6}{*}{10} & Asphalt & 7,595 & $\mathrm{~kg}$ & 12,000 & $91,140,000$ & \\
\hline & & & & & & $174,686,688.00$ \\
\hline & & & & & Total number & $174,686,688.00$ \\
\hline & & & & & VAT $10 \%$ & $17,468,668.80$ \\
\hline & & & & & Total & $192,155,356.80$ \\
\hline & & & & & be rounded & $192,155,000.00$ \\
\hline
\end{tabular}

\subsection{Analysis Preliminary Design}

Methods pime Frame construction work includes a sequence of jobs, among others:

1. Spadework

The preparatory work to be carried out include the measurement and fixing, Mobilization and Demobilization Heavy Equipment Reports Ass Build Documentation and Drawing

2. Roadworks

Excavated soil road work includes construction telford, telford LPB Embroidery Patch white stone, gravel Loose $\mathrm{t}$ grading on average $3 \mathrm{~cm}, 7 \mathrm{~cm}$ Lapis Penetration and Cleaning side ditch 


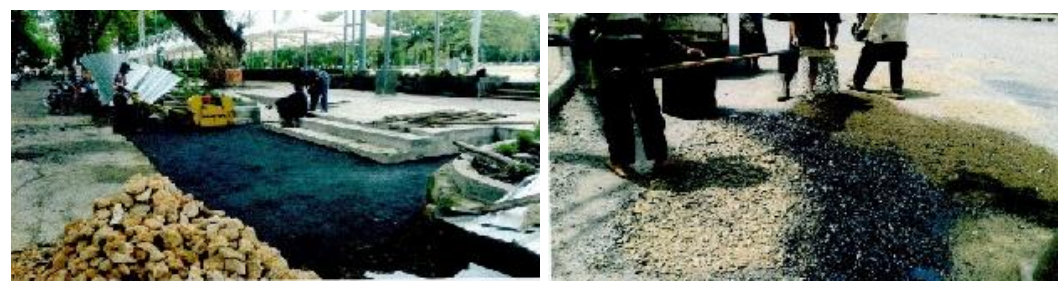

Figure 1. Embroidery Patch LPB Telford Batu Putih and Sow Sirtu Straighten Up T average $3 \mathrm{~cm}$

On the road maintenance work in District Purwodadi method because it can produce construction lataston Good, cheap and in accordance with local conditions. Lataston / HRS is adopted a mixture of mixture of types of Hot Rolled Asphalt (HRA) which was developed by the UK in accordance with the specifications of British Standards 594. Then in 1983, the Ministry of Public Works General Directorate Highways create guidelines and regulations on implementation guidelines Lapis thin asphalt concrete (flexible) (Lataston) to guarantee the quality of the road. Compared with dense graded asphalt concrete, Hot Rolled Sheet (HRS) graded unbalanced have easy to do, is spread and compacted when progress in the field.

Therefore, in order Lataston can meet the design life of pavement that is needed on a highway, then required treatment by using an additive that is relatively resistant to delay premature damage to the asphalt layer.

\subsection{Road Maintenance Self-Management System}

In the implementation of road maintenance work with a system of self-management, some order of the work carried out is the preliminary work and road work.

\section{Spadework}

The preparatory work to be carried out include the measurement and fixing, Mobilization and Demobilization Heavy Equipment Reports Ass Build Documentation and Drawing. 

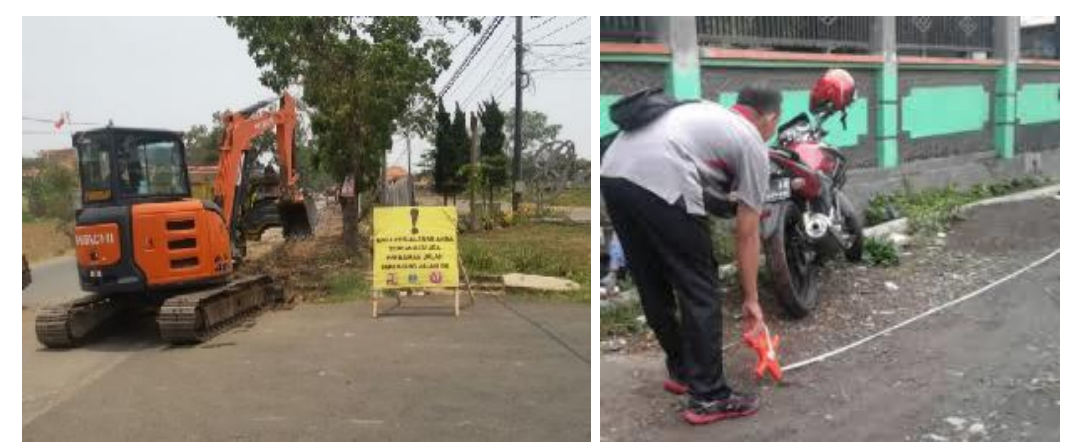

Figure 2. Job Introduction (Mobilization Tools and Measurement)

\section{Roadworks}

Excavated soil road work includes construction telford, telford LPB Embroidery Patch white stone, gravel Loose $\mathrm{t}$ grading on average $3 \mathrm{~cm}, 7 \mathrm{~cm}$ Lapis Penetration and Cleaning side ditch.

On the road maintenance work in District Purwodadi, use a surface layer of Hot Rolled Sheet (HRS) on the pavement, because the properties are impermeable of water included in the District of Purwodadi. Compared with other concrete asphalt, Hot Rolled Sheet (HRS) has resistance to fatigue / tiredness is quite high. mix aggregate Hot Rolled Sheet (HRS) consists of a graded aggregate gap, so that the mixture has a thick layer of asphalt. Therefore, the method Lataston / HRS can meet the design life of pavement required is 5 years.

Road construction work in the District Purwodadi using a thin layer of asphalt concrete/ HRS with white stone material as a patchwork of LPB telford previously undertaken telford construction excavation. While the size of $3 \mathrm{~cm}$ gravel sprinkled on top coating and layer thickness of $7 \mathrm{~cm}$ penetration following the planned construction cost calculations on road maintenance projects in the District of Purwodadi.

Table 2. Plan Road Maintenance Costs

\begin{tabular}{rlccccc}
\hline No. & \multicolumn{1}{c}{ commentary } & Volume & Analysis & $\begin{array}{c}\text { Unit Cost } \\
(\text { Rp. })\end{array}$ & Cost (Rp.) & Number (Rp.) \\
\hline I & $\begin{array}{l}\text { Spadework } \\
\text { leasurement and }\end{array}$ & Ls & Gauging & $500,000.00$ & $500,000.00$ & \\
1 & $\begin{array}{l}\text { Fixing } \\
\text { Demobilization } \\
2\end{array}$ & Lobilization Heavy & Ls & Gauging & $2,000,000.00$ & $2,000,000.00$ \\
$\begin{array}{l}\text { Equipment } \\
\text { Reports Ass Build } \\
\text { Documentation and }\end{array}$ & Ls & Gauging & $1,500,000.00$ & $1,500,000.00$
\end{tabular}


Vol 23 No 1 Tahun 2018

\begin{tabular}{|c|c|c|c|c|c|c|c|}
\hline No. & commentary & \multicolumn{2}{|c|}{ Volume } & Analysis & $\begin{array}{l}\text { Unit Cost } \\
\text { (Rp.) }\end{array}$ & Cost (Rp.) & Number (Rp.) \\
\hline & \multicolumn{7}{|l|}{ Drawing } \\
\hline & & & & & & & $4,000,000,00$ \\
\hline \multicolumn{8}{|c|}{ II ROADWORKS } \\
\hline 1 & $\begin{array}{l}\text { Telford construction } \\
\text { excavation } \\
\text { Embroidery Patch }\end{array}$ & 69.00 & M3 & K.224 & $61,305.00$ & $4,230,045,00$ & \\
\hline 2 & $\begin{array}{l}\text { LPB white stone } \\
\text { telford }\end{array}$ & 153.51 & M3 & K.516.B & $310,183.51$ & $47,616,270.62$ & \\
\hline 3 & $\begin{array}{l}\text { Sow sirtu } t \text { grading } \\
\text { on average } 3 \mathrm{~cm}\end{array}$ & 10.00 & M3 & Dihit & $326,686.50$ & $3,266,865.00$ & \\
\hline 4 & $\begin{array}{l}\text { Lapis Penetration } 7 \\
\mathrm{~cm}\end{array}$ & 96.00 & M3 & K.637 & $1,779,197.33$ & $170,802,943.68$ & \\
\hline \multirow[t]{6}{*}{5} & $\begin{array}{l}\text { Cleaning the side } \\
\text { ditch }\end{array}$ & 8.00 & M3 & K.424 & $10,490.61$ & $83,924.88$ & \\
\hline & & & & & & & $226,000,049.18$ \\
\hline & & & & & & amount & $230,000,049.18$ \\
\hline & & & & & & VAT $10 \%$ & $23,000,004.92$ \\
\hline & & & & & & Total & $253,000,054.10$ \\
\hline & & & & & & be rounded & $254,000,054.00$ \\
\hline
\end{tabular}

\subsection{Road Maintenance Contractual Systems (Conventional)}

In the implementation of road maintenance work with the contractual system, different methods of work performed by the method of work for road maintenance with self-managed system.

\section{Spadework}

Preliminary work with conventional systems that must be implemented similar to the system of self-management. The only difference is the procedural process contractual system (conventional) to be tendered work and a series of procedures including the issuance of the appointment of service providers, pre-construction meeting (precontstruction meeting), and Mutual Check Beginning to working drawings (soft drawing).

\section{Roadworks}

Road works on the system and the sequence of steps for contract discount work varies according to the method used by the maintenance contractor. But in general the work is covering Excavated soil road construction, Embroidery Patch LPB, Loose gravel grading above, Lapis Penetration and often also cleans the side ditch. The specifications for road works adapted to the current contractors bidding results tender process. 
On road maintenance work in District Purwodadi which uses contractual system uses road maintenance methods are different among others Laston (Layer of asphalt concrete), Latasir (thin layer of sand bitumen), Lataston (thin layer of asphalt concrete / HRS), SMA (Split Mastic Asphalt), HSMA (High Stiffness Modulus Asphalt) that is tailored to the nature and characteristics of each type of pavement.

However, the most widely used is latasir. Latasir produce construction less well when viewed the structure of the soil surface in the form Purwodadi Subdistrict young rock and clay is still soft. Therefore latasir method used by the contractors handling road maintenance often does not meet the design life of pavement required is 5 years. Most age latasir road maintenance only reached makismal 3 years.

Following calculation the planned construction costs on road maintenance projects in District Purwodadi with contractual system.

Table 3. Plan Road Maintenance Costs

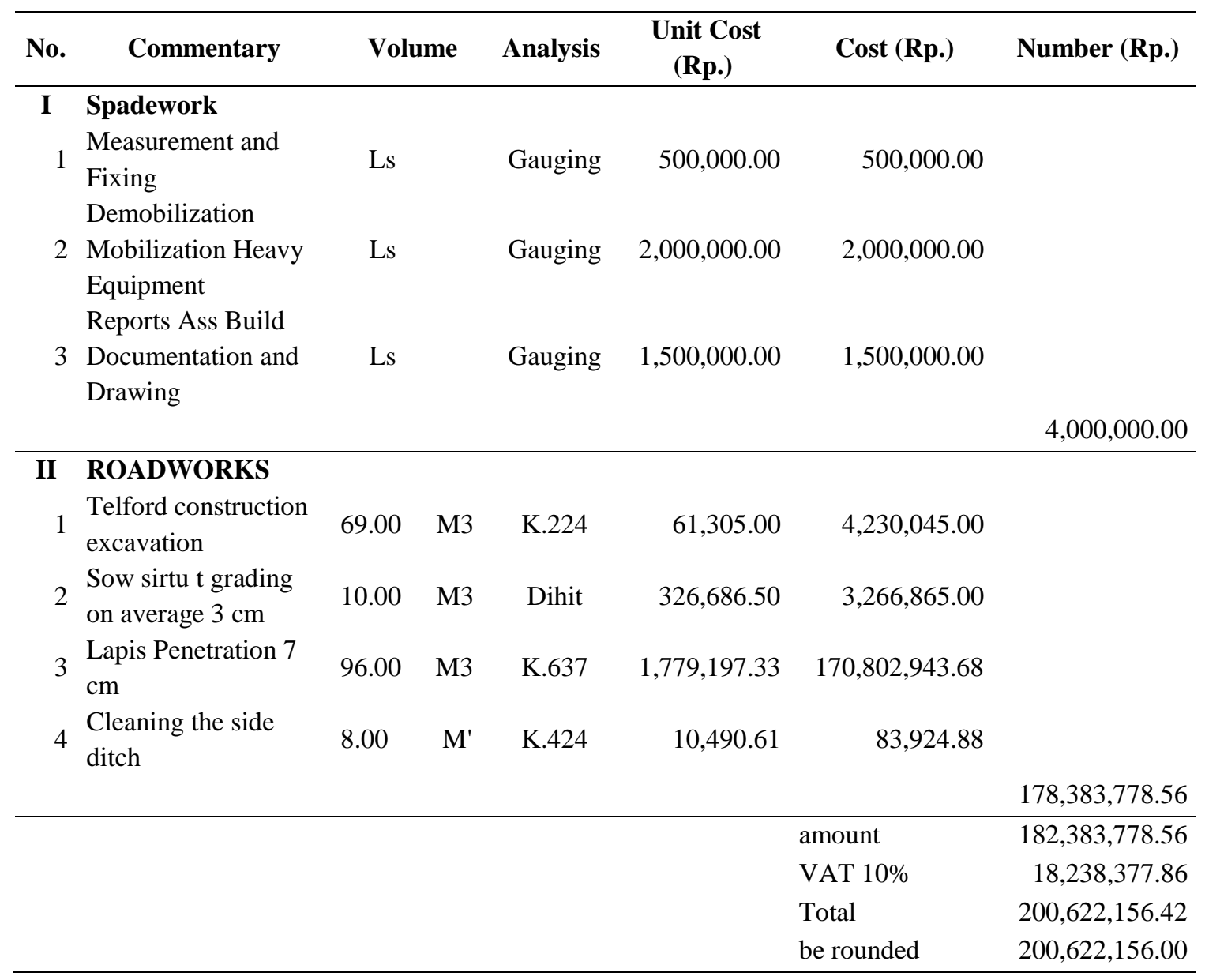




\subsection{Value Engineering Measured from Three Variable Quality Road Maintenance}

Value engineering on research It uses three variables to measure the quality of road maintenance in the District of Purwodadi good use contractual system and self-managed system.

\subsection{Comparison Variable Procedures}

The results of field interviews with respondents showed that there were significant differences between the procedures for the implementation of road maintenance between the contractual system with self-management system in the District of Purwodadi. These differences include the planning procedure, the auction procedures, procedures for implementation, monitoring procedures, procedures $\mathrm{CCO}$, disbursement procedures, and procedures PHO / FHO. In general, job execution procedures with self-management system more easily than the contractual system. It can be seen from a comparison of the average value of respondents were more likely to self-management system compared with the contractual system. These variables include the planning procedure, the auction procedures, procedures for implementation, monitoring procedures, $\mathrm{CCO}$ procedures, and procedures $\mathrm{PHO} / \mathrm{FHO}$.

\subsection{Comparison Variable Time}

Conclusion interviews for the time variable indicates that there is a significant difference betweenroad maintenance execution time between the contractual system with selfmanagement system in the District of Purwodadi. These differences include the auction time, the time of making the contract, report creation time, and the time of disbursement.

In general, the respondents said that the timing of the work with self-management system morefaster than the contractual system, among others, the auction time, the time of making the contract, and the time of disbursement. Only one variable is the time of making a report to prove that the manufacture of a progress report on the work of the contractual system faster than the system of self-management. In the contractual system the time required to conductauction could reach more than 1 month. It depends on the number of work packages being tendered. 
At the time of preparation of the self-managed systems only work 1-2 weeks, for implementation work not done simultaneously between a package with other packages.

\subsection{Comparison Variable Quality}

The results show that there is a difference between the quality / quality of the results of the road maintenance work in Purwodadi sub-district. These differences include the quality of the planning survey, the accuracy of the planning volume estimation, the adequacy of the number of field supervisors, the conformity of the planned volume with the realization, the quality of the work, and the level of comfort of the road users' driving. Based on the average comparison of respondents' answers, the quality of the results of the implementation of work with self-managed system is better than the contractual system.

A self-managed system of self-managed systems, the maintenance of the road system is a self-management that can be recommended for routine maintenance activities undertaken on the road in the district of Purwodadi ie self-managed system with methods lataston / HRS because it has properties that impermeable of water. Compared with other concrete asphalt, Hot Rolled Sheet (HRS) has resistance to fatigue / tiredness is quite high. Therefore, the method Lataston / HRS can meet the design life of pavement needed is five years evensecara higher price of Rp. 253,000,054.00 - compared to the original plan of Rp. 192,155,000.00 benefited Rp. 60,845,054.00 -. However, in terms of durability or durability according to the age of the plan is 5 years compared with the contractual system that is only 2-3 years old. In addition, self-managed systems have easier procedures, faster execution time and better quality of work results.

\section{CONCLUSION}

After analyzed in the previous chapter, then on this conclusion will be presented the results of this study among others :

1. Self-managed system is appropriate for routine road maintenance in Kecamatan Purwodadi by lataston / HRS method because it has water-resistant properties.

2. Lataston / HRS method can fulfill the life of the road pavement plan required ie 5 years although the price is higher that is $\mathrm{Rp} .253,000,054.00$, - compared to the original plan of Rp. 192,155,000.00, - benefited Rp. 60,845,054.00 -. 
3. Value engineering on road maintenance between self-managed and contractual (conventional) systems can provide a quality road maintenance outcome through three variables where conventional systems have easier procedures, faster implementation times and better quality of work results than contractual systems.

\section{REFERENCES}

Alfan NR, 2014, Parking Planning Study In Malang Region Olympic Garden, Universitas Brawijaya, Malang.

Black, 1981, Transport Planning and Modeling : Theory and Practice, Cromm Helm, London.

D. Mile, L, 1972. Technique of Value Analysis and engineering. Kcdua edition. The McGraw-Hill Companies, New York

DeGarmo, EP, WG Sullivan, JR Canada. 1984, Engineering Economy, Seventh Edition, Macmillan Publishing Company.

Directorate General of Land Transportation, Directorate of City Traffic and Transportation System, Ministry of Transportation. 1998, Guidelines for Planning and Operation of Parking Facility, Jakarta.

Khisty, Jotin and B. Kent Lall. 2003. Fundamentals of Transportation Engineering Volume 1. Erlangga. Jakarta.

Kodoatie, Robert J. 1995. Technical Economic Analysis, Yogyakarta: Andi

Mulyadi, 2005, Cost Accounting, STIE YKPN, Yogyakarta.

Munawar, A. 2004, Urban Traffic Management, Beta Offset, Jogjakarta.

PC, Box. and C. Oppenlander, Josepsh. 1976. Manual of Trafic Engineering Studies, 4th edition. Washington, DC: Institute of Transportation Engineers.

Saridewi, 2009, Parking Demand Analysis at Various Lands in Legian Kuta Bali, National Seminar on Regional Needs, ITS Surabaya

Soeharto, Faith. 1995. Project Management: From Conceptual to Operational. Jakarta: Erland.

Soeharto, I. 1995. Manajemen Proyek: Dari Konseptual Sampai Operasional. Jakarta: Erlangga. 